\title{
GPS2 Gene
}

National Cancer Institute

\section{Source}

National Cancer Institute. GPS2 Gene. NCI Thesaurus. Code C24453.

This gene plays a role in suppression of signal transduction. 